Article

\title{
Derivatization of Natural Compound $\beta$-Pinene Enhances Its In Vitro Antifungal Activity against Plant Pathogens
}

\author{
Yunfei Shi ${ }^{1, \dagger}{ }^{\dagger}$ Hongyan $\mathrm{Si}^{1,+}{ }^{\dagger}$, Peng Wang ${ }^{1}$, Shangxing Chen ${ }^{1}$, Shibin Shang ${ }^{2}$, Zhanqian Song ${ }^{2}$, \\ Zongde Wang ${ }^{1, *}$ and Shengliang Liao ${ }^{1, * \mathbb{D}}$ \\ 1 College of Forestry, Jiangxi Agricultural University; National Forestry and Grassland Bureau Woody \\ Spice (East China) Engineering Technology Research Center; National Forestry and Grassland \\ Bureau/Jiangxi Provincial Camphor Engineering Technology Research Center; Collaborative Innovation \\ Center of Jiangxi Typical Trees Cultivation and Utilization, Nanchang 330045, China \\ 2 Institute of Chemical Industry of Forest Products, Chinese Academy of Forestry, Nanjing 210042, China \\ * Correspondence: zongdewang@163.com (Z.W.); liaosl@jxau.edu.cn (S.L.) \\ $\dagger$ These authors contributed equally to this work.
}

Received: 22 July 2019; Accepted: 28 August 2019; Published: 29 August 2019

\begin{abstract}
Background: The development of new antifungal agents has always been a hot research topic in pesticide development. In this study, a series of derivatives of natural compound $\beta$-pinene were prepared, and the antifungal activities of these derivatives were evaluated. The purpose of this work is to develop some novel molecules as promising new fungicides. Methods: Through a variety of chemical reactions, $\beta$-pinene was transformed into a series of $\beta$-pinene-based derivatives containing amide moieties and acylthiourea moieties. The antifungal activities of these derivatives against five plant pathogens including Colletotrichum gloeosporioides, Fusarium proliferatum, Alternaria kikuchiana, Phomopsis sp. and Phytophthora capsici were tested; preliminary structure-activity relationship was discussed. Results: Some derivatives exhibited moderate or significant antifungal activity due to the fusion of the amide moiety or the acylthiourea moiety with the pinane skeleton. The structure-activity relationship analysis showed that the fluorine atom and the strong electron withdrawing nitro group, or trifluoromethyl group on the benzene ring of the derivatives had a significant effect on the improvement of the antifungal activity against Colletotrichum gloeosporioides, Fusarium proliferatum, Alternaria kikuchiana and Phomopsis sp. Meanwhile, the introduction of an ethyl group at the meta-position on the benzene ring of the derivatives could improve the antifungal activity against Phytophthora capsici. Compounds 4e, 4h, 4q, 4r exhibited broad-spectrum antifungal activity against the tested strains. Compound 40 had significant antifungal activity against Phytophthora capsici $\left(\mathrm{IC}_{50}=0.18 \mu \mathrm{mol} / \mathrm{L}\right)$. These derivatives were expected to be used as precursor molecules for novel pesticide development in further research.
\end{abstract}

Keywords: pinene; myrtanyl acid; amide; acylthiourea; antifungal activity

\section{Introduction}

During the growth of crops, various plant diseases occur; $70 \%$ to $80 \%$ of plant diseases are caused by phytopathogenic fungi infection [1,2]. When infecting crops, plant pathogenic fungi can not only directly reduce the yield and quality of crops, but also secrete a variety of toxins and metabolites that are harmful to humans and animals, causing a huge threat to human health [3]. Therefore, effective and safe inhibition of growth of plant pathogenic fungi has become the key to control plant diseases.

Chemical antifungal agents can effectively kill or inhibit the growth of plant pathogenic fungi, and play a vital role in protecting human health, increasing crop yields, and food preservation $[4,5]$. 
However, a long-term usage of the same antifungal agent often leads to an increase in the resistance of phytopathogenic fungi [6,7]. Continuous development of new antifungal agents is still the active demand, and the development of new antifungal agents has also been a hot spot in pesticide research.

The compound $\beta$-pinene is a natural compound with antimicrobial activity [8-10] which can be used to participate in numerous chemical reactions. Masses of $\beta$-pinene derivatives can be synthesized by chemical modification, and some of these derivatives have been proved to have better antifungal activity [11-17]. For example, Li et al. [14] synthesized three series of $\beta$-pinene-based derivatives, and tested their fungicidal activity against three agricultural fungi. As a result, there two derivatives displayed potent fungicidal activity against Rhizoctonia solani, with $\mathrm{IC}_{50}$ values of 2.439 and $1.857 \mathrm{mg} / \mathrm{mL}$. Thus, $\beta$-pinene was treated as a good precursor compound for the development of plant-derived pesticides. Based on previous results, in this study, $\beta$-pinene was used as a raw material to design and synthesize a series of derivatives through splicing of different bioactive substructures, aiming to obtain derivatives with stronger antifungal activity against plant pathogenic fungi. This study can provide a reference for the development of novel potent plant-derived antifungal agents.

\section{Results}

\subsection{Chemisty}

We carried out a series of modifications of $\beta$-pinene (Figure 1). Firstly, $\beta$-pinene was converted to myrtanol by a hydroboration reaction, and the myrtanol was oxidized to myrtanyl acid by an oxidation reaction. Then, based on the substructure splicing principle, a series of amide derivatives and acylthiourea derivatives were synthesized by splicing an amide moiety or an acylthiourea moiety onto the pinane skeleton.

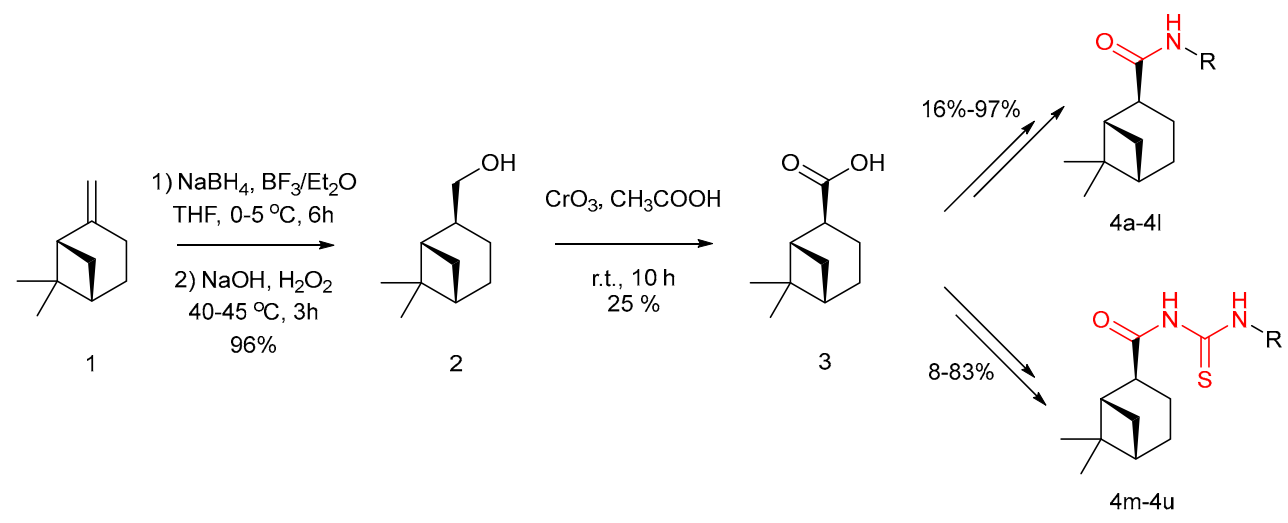

Figure 1. Synthesis route of the $\beta$-pinene-based derivatives.

The molecular structures of $\beta$-pinene-based derivatives were characterized by IR, NMR and MS. The results showed that the target derivatives $\mathbf{2 ,}, \mathbf{3}, \mathbf{4 a}-\mathbf{4 l}$ and $\mathbf{4 m}-\mathbf{4} \mathbf{u}$ were successfully synthesized in this study.

Taking compound $4 \mathbf{k}$ as an example to analyze the characterization of $\beta$-pinene-based amide derivatives, the FT-IR spectrum of $4 \mathbf{k}$ showed an absorption band at $3432 \mathrm{~cm}^{-1}$ due to the new amide $\mathrm{N}-\mathrm{H}$ group and the characteristic stretching frequency of $\mathrm{C}=\mathrm{O}$ was observed at $1687 \mathrm{~cm}^{-1}$ and $1654 \mathrm{~cm}^{-1}$. In the ${ }^{1} \mathrm{H}$ NHR spectrum of compound $4 \mathbf{k}$, the proton signal of $\mathrm{N}-\mathrm{H}$ was observed as a singlet at $\delta 11.91 \mathrm{ppm}$. Aliphatic protons were observed in the range of $\delta 0.85-3.24 \mathrm{ppm}$. Aromatic protons appeared in the range of $\delta 7.02-7.64 \mathrm{ppm}$. The signal of the thiazole proton appeared in $\delta$ $7.74 \mathrm{ppm}$. In the ${ }^{13} \mathrm{C}$ NMR spectrum of compound $4 \mathbf{k}$, the characteristic amide $\mathrm{C}=\mathrm{O}$ was observed at $173.66 \mathrm{ppm}$ which confirmed the amide bond was formed between the pinane skeleton and phenylthiazole. The mass spectrum of $4 \mathbf{k}$ showed an expected molecular ion peak at $\mathrm{m} / \mathrm{z} 345.1$ $[\mathrm{M}+\mathrm{H}]^{+}, 343.1[\mathrm{M}-\mathrm{H}]^{-}$corresponding to molecular formula.

In addition, taking compound $4 \mathrm{~m}$ as an example to analyze the characterization of $\beta$-pinene-based acylthiourea derivatives, the FT-IR spectrum of $4 \mathrm{~m}$ exhibited an absorption wavelength at $1686 \mathrm{~cm}^{-1}$ 
corresponding to a $\mathrm{C}=\mathrm{O}$ group, and the absorption wavelengthsat $1143 \mathrm{~cm}^{-1}$ and $1102 \mathrm{~cm}^{-1}$ belonging to a $\mathrm{C}=\mathrm{S}$ group. The acylthiourea $\mathrm{N}-\mathrm{H}$ group was observed at $3635 \mathrm{~cm}^{-1}$. The characteristic absorption band of the C-N group of acylthiourea appeared at $1327 \mathrm{~cm}^{-1}, 1310 \mathrm{~cm}^{-1}$ and $1296 \mathrm{~cm}^{-1}$. In the ${ }^{1} \mathrm{H}$ NHR spectrum of compound $4 \mathrm{~m}$, the signal related to the proton of thiourea at $\delta 12.47 \mathrm{ppm}$ appeared. All other aromatic and aliphatic region protons were observed at an acceptable range. In the ${ }^{13} \mathrm{C}$ NMR spectrum of compound $4 \mathrm{~m}$, the $\mathrm{C}=\mathrm{O}$ and $\mathrm{C}=\mathrm{S}$ groups of the acylthiourea were observed in $\delta$ $178.33 \mathrm{ppm}$ and $\delta 176.81 \mathrm{ppm}$, respectively. The mass spectrum of $4 \mathrm{~m}$ showed an expected molecular ion peak at $\mathrm{m} / z 325.1[\mathrm{M}+\mathrm{Na}]^{+}$and $301.2[\mathrm{M}-\mathrm{H}]^{-}$corresponding to the molecular formula.

The spectral data of these compounds can be found in the Supplementary Materials.

\subsection{Biological Activity}

The antifungal activities of the $\beta$-pinene-based derivatives against five plant pathogens are shown in Table 1. The antifungal activity of the $\beta$-pinene-based derivatives against Colletotrichum gloeosporioides showed that there were five derivatives $(4 \mathbf{e}, \mathbf{4 g}, \mathbf{4 h}, \mathbf{4} \mathbf{j}$ and $4 \mathbf{r})$ with $\mathrm{IC}_{50}$ values less than $200 \mu \mathrm{mol} / \mathrm{L}$. Among them, the acylthiourea derivative $4 \mathrm{r}$ had the highest antifungal activity, and its $\mathrm{IC}_{50}$ value was $21.64 \mu \mathrm{mol} / \mathrm{L}$. For the Fusarium proliferatum, it was shown that there were five compounds (4a, 4e, 4g, $4 \mathbf{h}$ and $\mathbf{4 q}$ ) with $\mathrm{IC}_{50}$ values below $200 \mu \mathrm{mol} / \mathrm{L}$, and the amide derivatives $4 \mathbf{e}$ and $4 \mathrm{~h}$ had better activities; their $\mathrm{IC}_{50}$ values were $39.21 \mu \mathrm{mol} / \mathrm{L}$ and $41.98 \mu \mathrm{mol} / \mathrm{L}$, respectively. For the Alternaria kikuchiana, the $\mathrm{IC}_{50}$ values of five amide derivatives $(4 \mathbf{a}, 4 \mathbf{b}, 4 \mathbf{c}, 4 \mathbf{e}$ and $4 \mathbf{h})$ were less than $200 \mu \mathrm{mol} / \mathrm{L}$, and compound $4 \mathbf{e}$ exerted the best antifungal activity $\left(\mathrm{IC}_{50}=38.8 \mu \mathrm{mol} / \mathrm{L}\right)$. The antifungal activity of the $\beta$-pinene-based derivatives against Phomopsis sp. showed that most of the derivatives had certain inhibitory effects on Phomopsis sp., and the $\mathrm{IC}_{50}$ of 11 derivatives $(4 \mathrm{a}, 4 \mathrm{c}, 4 \mathrm{~d}, 4 \mathrm{e}, \mathbf{4 h}, \mathbf{4 i}, \mathbf{4 j}, \mathbf{4 m}, \mathbf{4 0}, \mathbf{4 q}$ and 4r) were less than $200 \mu \mathrm{mol} / \mathrm{L}$. The amide derivative $4 \mathrm{~h}$ had the best effect on the Phomopsis sp., and its $\mathrm{IC}_{50}$ value was $20.43 \mu \mathrm{mol} / \mathrm{L}$.

Compared with the intermediate compound myrtanyl acid, only compounds $4 \mathbf{d}, \mathbf{4 o}, \mathbf{4 q}$ and $4 \mathrm{r}$ exhibited better antifungal activity against Phytophthora capsici. Among them, compound $4 \mathbf{o}$ displayed potent antifungal activity against Phytophthora capsici, and its $\mathrm{IC}_{50}$ value was $0.18 \mu \mathrm{mol} / \mathrm{L}$, which was lower than that of the positive control carbendazim against Phytophthora capsici. 
Table 1. $\mathrm{IC}_{50}$ values of $\beta$-pinene-based derivatives against five plant pathogens $(\mu \mathrm{mol} / \mathrm{L})$.

\begin{tabular}{|c|c|c|c|c|c|c|c|}
\hline Compounds & Skeleton & $\mathbf{R}$ & $\begin{array}{l}\text { Colletotrichum } \\
\text { gloeosporioides }\end{array}$ & $\begin{array}{c}\text { Fusarium } \\
\text { proliferatum }\end{array}$ & $\begin{array}{l}\text { Alternaria } \\
\text { kikuchiana }\end{array}$ & Phomopsis sp. & $\begin{array}{l}\text { Phytophthora } \\
\text { capsici }\end{array}$ \\
\hline 1 & & - & $>1000$ & $>1000$ & $>1000$ & $>1000$ & $>1000$ \\
\hline 2 & & - & $>1000$ & $>1000$ & $>1000$ & $>1000$ & $>1000$ \\
\hline 3 & & - & $>1000$ & 417.54 & $>1000$ & $>1000$ & 224.10 \\
\hline $4 a$ & & & 364.60 & 147.38 & 134.62 & 98.89 & 626.25 \\
\hline $4 b$ & & & $>1000$ & 554.30 & 151.44 & 270.73 & 423.72 \\
\hline $4 c$ & & & 755.05 & 397.69 & 64.17 & 68.35 & 499.01 \\
\hline $4 d$ & & & $>1000$ & 200.61 & $>1000$ & 123.45 & 140.99 \\
\hline $4 e$ & & & 161.40 & 39.21 & 38.80 & 40.98 & NT \\
\hline
\end{tabular}


Table 1. Cont.

\begin{tabular}{|c|c|c|c|c|c|c|c|}
\hline Compounds & Skeleton & $\mathbf{R}$ & $\begin{array}{l}\text { Colletotrichum } \\
\text { gloeosporioides }\end{array}$ & $\begin{array}{c}\text { Fusarium } \\
\text { proliferatum }\end{array}$ & $\begin{array}{c}\text { Alternaria } \\
\text { kikuchiana }\end{array}$ & Phomopsis sp. & $\begin{array}{l}\text { Phytophthora } \\
\text { capsici }\end{array}$ \\
\hline $4 f$ & & & $>1000$ & $>1000$ & $>1000$ & $>1000$ & NT \\
\hline $4 g$ & & & 165.61 & 72.84 & 240.96 & 335.23 & NT \\
\hline $4 h$ & & & 77.06 & 41.98 & 68.17 & 20.43 & 350.63 \\
\hline $4 \mathbf{i}$ & & & 346.00 & 376.94 & 389.92 & 112.70 & 864.54 \\
\hline $4 \mathbf{j}$ & & & 179.64 & 549.59 & 320.34 & 184.46 & 375.65 \\
\hline $4 k$ & & & $>1000$ & $>1000$ & $>1000$ & 490.82 & NT \\
\hline 41 & & & $>1000$ & NT & $>1000$ & 217.90 & $>1000$ \\
\hline $4 m$ & & & $>1000$ & $>1000$ & 894.20 & 120.23 & $>1000$ \\
\hline $4 n$ & & & $>1000$ & $>1000$ & $>1000$ & $>1000$ & $>1000$ \\
\hline 40 & & & 498.34 & $>1000$ & $>1000$ & 136.54 & 0.18 \\
\hline
\end{tabular}


Table 1. Cont

\begin{tabular}{|c|c|c|c|c|c|c|c|}
\hline Compounds & Skeleton & $\mathbf{R}$ & $\begin{array}{l}\text { Colletotrichum } \\
\text { gloeosporioides }\end{array}$ & $\begin{array}{c}\text { Fusarium } \\
\text { proliferatum }\end{array}$ & $\begin{array}{c}\text { Alternaria } \\
\text { kikuchiana }\end{array}$ & Phomopsis sp. & $\begin{array}{l}\text { Phytophthora } \\
\text { capsici }\end{array}$ \\
\hline $4 p$ & & & $>1000$ & $>1000$ & $>1000$ & $>1000$ & $>1000$ \\
\hline $4 q$ & & & $>1000$ & 143.84 & $>1000$ & 60.25 & 157.76 \\
\hline $4 r$ & & & 21.64 & 492.13 & 341.24 & 109.93 & 176.39 \\
\hline $4 s$ & & & $>1000$ & $>1000$ & $>1000$ & $>1000$ & $>1000$ \\
\hline $4 t$ & & & $>1000$ & 555.32 & $>1000$ & 240.79 & 557.82 \\
\hline carbendazim & & & 0.534 & 0.426 & 0.431 & 0.217 & 0.386 \\
\hline
\end{tabular}

Note: NT means not tested. 


\section{Discussion}

Both the amide structure and the acylthiourea structure are important antifungal active sub-structural units. Amide compounds have been used as fungicides for decades. Up to now, more than 30 varieties have been commercialized, such as ethaboxam, metalaxyl, thifluzamide, etc. (see Figure 2).

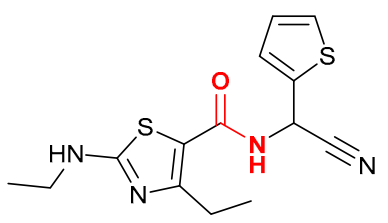

Ethaboxam

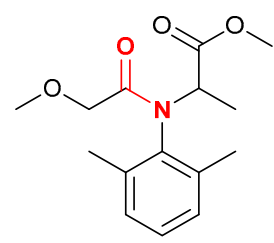

Metalaxyl

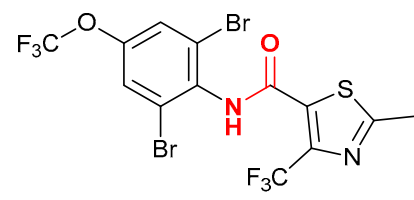

Thifluzamide

Figure 2. Typical commercial amide fungicides.

Acylthioureas also exhibit good antifungal activity. For example, Antypenko et al. reported a series of acylthiourea derivatives with good activity against fungi and Phytophthora pathogens [18]. Qin et al. reported that chitosan-based thiourea derivatives containing 1,2,4-triazole heterocycles had good antifungal activity against plant pathogenic bacteria [19]. Li et al. reported that a series of decanoic acid thiourea derivatives have good antifungal activity against various plant pathogenic fungi [14]. Gao et al. reported that a series of terpene-based acyl-thiourea derivatives showed moderate to excellent antifungal activities against several fungi $[16,17]$.

Since the amide structure and the acylthiourea structure are the key structures for exerting antifungal activity, when designing the $\beta$-pinene-based derivatives, we blended the amide moiety or the acylthiourea moiety into the pinane skeleton, in order to obtain new hybrids with good antifungal activity.

The antifungal activity of the synthesized derivatives against five plant pathogens was tested in this work. These five plant pathogens were Colletotrichum gloeosporioides, Fusarium proliferatum, Alternaria kikuchiana, Phomopsis sp. and Phytophthora capsici. Colletotrichum gloeosporioides is one of the most serious pathogenic fungi of Camellia oleifera. If infected with this fungus, the yield of Camellia oleifera will be reduced significantly [20]. Fusarium proliferatum is a cause of many crop diseases, including rice spikelet rot disease [21], stem rot of Hylocereus polyrhizus [22], root rot in soybean [23], etc. Alternaria kikuchiana is the pathogen of pear black spot disease. It infects the fruits, leaves and shoots of different varieties of pear trees, causing the leaves of pear trees to fall, early fruit drop, fruit decay and shedding, post-harvest decay, etc [24]. Phomopsis sp. may cause leaf spot, fruit rot and postharvest fruit rot of kiwifruit $[25,26]$. Phytophthora capsici can infect various growth stages of pepper plants, causing seedling death, root rot, crown rot, stem blight, leaf spot and fruit rot $[27,28]$. Hence, it is of great significance to develop new antifungal agents for controlling these fungi.

The results of antifungal activity test showed that compared with the raw material $\beta$-pinene and the intermediate compound myrtanyl acid, $\beta$-pinene-based derivatives that were synthesized by the blend of amide group and pinane skeleton or the blend of acylthiourea group and pinane skeleton exerted better antifungal activity against plant pathogens. Some derivatives exhibited moderate to significant antifungal activity. In general, the antifungal activity of amide derivatives against Colletotrichum gloeosporioides, Fusarium proliferatum and Alternaria kikuchiana was better than that of acylthiourea derivatives. However, the antifungal activity of acylthiourea derivatives against Phytophthora capsici was better than that of amide derivatives.

Although it is hard to give a comprehensive structure-activity relationship to these derivatives, we can find some interesting hints from Table 1. For Colletotrichum gloeosporioides, the four most potent compounds were $4 \mathrm{r}<4 \mathrm{~h}<4 \mathrm{e}<4 \mathrm{~g}$. For Fusarium proliferatum, the three most potent compounds were $4 \mathbf{e}<4 \mathbf{h}<\mathbf{4 g}$. For Alternaria kikuchiana, the three most potent compounds were $4 \mathbf{e}<4 \mathbf{h}<\mathbf{4 c}$. For Phomopsis sp., the three most potent compounds were $4 \mathbf{h}<4 \mathbf{e}<\mathbf{4 q}$. These results revealed 
that an introduced fluorine atom (4r and $4 \mathrm{~g}$ ), nitro group (4h) or trifluoromethyl group (4e) at the para-position on the benzene ring of the derivatives could significantly improve the antifungal activity. Besides, the introduction of a bromine atom $(\mathbf{4})$ or fluorine atom $(\mathbf{4 q})$ at the ortho-position on the benzene ring of the derivatives could also improve the antifungal activity against the above-mentioned fungi. For Phytophthora capsici, the four most potent compounds were $4 \mathbf{o}<4 \mathbf{d}<4 \mathbf{q q}<4 \mathbf{r}$, which suggested that introduction of an ethyl group at the meta-position on the benzene ring of the derivatives could improve the antifungal activity against Phytophthora capsici. It was reported that the incorporation of fluorine into a biologically active compound might simultaneously influence the electronic, lipophilic and steric parameters and might therefore, in the ideal case, critically increase the intrinsic activity and the chemical and metabolic stability but also improved the pharmacokinetics [29]. In this study, it was believed that the capacity of fluorine was to enhance the metabolic stability of the antifungal derivatives in the fungi body, mainly by lowering the susceptibility of nearby moieties to cytochrome P450 enzymatic oxidation. Besides, fluorine atoms, nitro groups or trifluoromethyl groups were electron withdrawing groups. They could decrease the electron cloud density and influence the molecular surface charge distribution of antifungal derivatives through the inductive effect or conjugation. Furthermore, these group might offer more binding sites for receptor-ligand interactions, which may relatively enhance the antifungal activity [30-36].

\section{Materials and Methods}

\subsection{General}

Melting points were determined in WRS-2 melting point apparatus (Shanghai Precision \& Scientific Instrument Co., Ltd., Shanghai, China) and were uncorrected. IR spectra were recorded on a Nicolet IS10 FT-IR spectrometer (Nicolet, Madison, WI, USA). ${ }^{1} \mathrm{H}$ NMR and ${ }^{13} \mathrm{C}$ NMR spectra were recorded on a Bruker DKX500 NMR spectrometer (Bruker, Karlsruhe, Germany) using $\mathrm{CDCl}_{3}$ as solvent, and TMS as internal standard. ESI-MS were recorded on a Waters Q-TOF MicroTM mass spectrometer. Purity of compounds was detected by Agilent 1260 high performance liquid chromatography (Agilent, Santa Clara, CA, USA) and Fuli GC-9750 gas chromatography (Zhejiang Fuli analysis instrument Co. Ltd., Wenling, China). All reactions were traced by the thin layer chromatography (TLC). The compound $(-)-\beta$-pinene was purchased from the spice company Jiangxi Jishui Hongda Natural Perfume Co., Limited, Ji'an, China, and other reagents were of reagent grade. Fungi were isolated by the plant pathology laboratory in the College of Agriculture, Jiangxi Agricultural University.

\subsection{Synthesis of Derivatives}

Following the procedures described in our previous reports $[37,38]$, the $\beta$-pinene derivatives involved in this work was prepared as follows:

\subsubsection{Synthesis of Myrtanol (Compound 2)}

To a solution of $(-)-\beta$-pinene $(0.4 \mathrm{~mol})$ and sodium borohydride $(0.15 \mathrm{~mol})$ in dry tetrahydrofuran $(200 \mathrm{~mL}), 47 \%$ boron trifluoride ether solution $(0.2 \mathrm{~mol})$ was added and the mixture was stirred at $0-5{ }^{\circ} \mathrm{C}$. After $6 \mathrm{~h}$, ethanol $(30 \mathrm{~mL})$ was added to quench the hydroboration reaction. Then, a $3 \mathrm{~mol} / \mathrm{L}$ sodium hydroxide aqueous solution $(68 \mathrm{~mL})$ and the $30 \%$ hydrogen peroxide $(60 \mathrm{~mL})$ were added in succession. The mixture was stirred at $40-45^{\circ} \mathrm{C}$. After $3 \mathrm{~h}$, saturated sodium thiosulfate solution $(40 \mathrm{~mL})$ was added to exhaust excessive amounts of hydrogen peroxide. The reaction mixture was evaporated under reduced pressure to remove the organic phase. The residues were extracted with ethyl acetate $(3 \times, 100 \mathrm{~mL})$. The resulting organic phase was washed by water $(3 \times, 100 \mathrm{~mL})$ and brine $(100 \mathrm{~mL})$, dried over sodium sulfate, filtered, and concentrated under vacuum to afford myrtanol (compound 2 ) as a colorless liquid. The characterization data of compound $\mathbf{2}$ were shown in Table 2. 
Table 2. Characterization data of myrtanol.

\begin{tabular}{cl}
\hline Compound & \multicolumn{1}{c}{ Characterization Data } \\
\hline & Colorless liquid; yield 96.8\%; purity 94.5\%; FT-IR v $\left(\mathrm{cm}^{-1}\right): 3313(\mathrm{O}-\mathrm{H}), 1041(\mathrm{C}-\mathrm{O}) ;{ }^{1} \mathrm{H}$ NMR \\
& $(300 \mathrm{MHz}, \mathrm{CDCl} 3) \delta: 3.55(\mathrm{dd}, J=7.6,5.2 \mathrm{~Hz}, 2 \mathrm{H}), 2.44-2.31(\mathrm{~m}, 1 \mathrm{H}), 2.31-2.14(\mathrm{~m}, 1 \mathrm{H})$, \\
2 & $2.05-1.97(\mathrm{~m}, 2 \mathrm{H}), 1.98-1.78(\mathrm{~m}, 4 \mathrm{H}), 1.54-1.35(\mathrm{~m}, 1 \mathrm{H}), 1.19(\mathrm{~s}, 3 \mathrm{H}), 0.97(\mathrm{~s}, 3 \mathrm{H}), 0.93$ \\
& $(\mathrm{~d}, J=9.6 \mathrm{~Hz}, 1 \mathrm{H}) .{ }^{13} \mathrm{C} \mathrm{NMR}\left(75 \mathrm{MHz}, \mathrm{CDCl}_{3}\right) \delta: 66.95,43.77,42.37,40.93,38.07,32.63,27.44$, \\
& $25.48,22.79,18.29 . \mathrm{GC}-\mathrm{MS} \mathrm{m} / \mathrm{z}=154.1[\mathrm{M}]^{+}$. \\
\hline
\end{tabular}

\subsubsection{Synthesis of Myrtanyl Acid (Compound 3)}

Myrtanol (0.2 mol) was dissolved in glacial acetic acid $(200 \mathrm{~mL})$, and the solution was slowly added to a solution of chromic anhydride $(0.6 \mathrm{~mol})$ in glacial acetic acid $(250 \mathrm{~mL})$ and water $(50 \mathrm{~mL})$. The mixture was stirred at room temperature. After $10 \mathrm{~h}$, the mixture was poured into water, and precipitate was collected through filtration. The obtained precipitate was dissolved in saturated sodium hydroxide aqueous solution, extracted with EtOAc $(2 \times, 50 \mathrm{~mL})$. The resulting aqueous phase was neutralized by $10 \%$ hydrochloric acid, extracted with EtOAc $(3 \times, 50 \mathrm{~mL})$. The resulting organic phase was washed by water $(3 \times, 50 \mathrm{~mL})$ and brine $(50 \mathrm{~mL})$, dried over sodium sulfate, filtered, and concentrated under vacuum to afford myrtanyl acid (compound 3 ) as a white solid. The characterization data of compound 3 were shown in Table 3.

Table 3. Characterization data of myrtanyl acid.

\begin{tabular}{cc}
\hline Compound & Characterization Data \\
\hline & White solid; m.p. 92-94 ${ }^{\circ} \mathrm{C} ;$ yield 24.5\%; purity 98.7\%; FT-IR v $\left(\mathrm{cm}^{-1}\right): 3660,3638,3061(\mathrm{O}-\mathrm{H})$, \\
& $2990,2950,2920,2903,2869(\mathrm{C}-\mathrm{H}), 1675(\mathrm{C}=\mathrm{O}), 1478,1458(\mathrm{C}-\mathrm{H}), 1414(\mathrm{O}-\mathrm{H}), 1386,1364,1338$, \\
3 & $1320(\mathrm{C}-\mathrm{H}), 1250(\mathrm{C}-\mathrm{O}), 940(\mathrm{O}-\mathrm{H}) .{ }^{1} \mathrm{H} \mathrm{NMR}\left(500 \mathrm{MHz}, \mathrm{CDCl}_{3}\right) \delta: 11.91(\mathrm{~s}, 1 \mathrm{H}), 3.02$ \\
& $(\mathrm{dt}, J=10.3,3.5 \mathrm{~Hz}, 1 \mathrm{H}), 2.54(\mathrm{dd}, J=9.1,5.5 \mathrm{~Hz}, 1 \mathrm{H}), 2.42-2.29(\mathrm{~m}, 2 \mathrm{H}), 2.07-1.84(\mathrm{~m}, 4 \mathrm{H}), 1.26$ \\
& $(\mathrm{~s}, 3 \mathrm{H}), 1.23(\mathrm{~d}, J=10.0 \mathrm{~Hz}, 1 \mathrm{H}), 0.91(\mathrm{~s}, 3 \mathrm{H}) .{ }^{13} \mathrm{C} \mathrm{NMR}(126 \mathrm{MHz}, \mathrm{CDCl})_{3} \delta: 183.04,43.76,42.98$, \\
& $40.34,38.74,29.03,26.88,24.60,21.51,15.09$. ESI-MS: $m / z 191.1\left[\mathrm{M}+\mathrm{Na}^{+} ; 167.1[\mathrm{M}-\mathrm{H}]^{-}\right.$. \\
\hline
\end{tabular}

\subsubsection{Synthesis of Myrtanyl Acid Amide Derivatives (Compound 4a-4l)}

A solution of myrtanyl acid $(20 \mathrm{mmol})$ and oxalyl chloride $(30 \mathrm{mmol})$ in dry dichloromethane $(20 \mathrm{~mL})$ was stirred at $50{ }^{\circ} \mathrm{C}$ for $4 \mathrm{~h}$. Then, the reaction mixture was evaporated under reduced pressure to remove the organic phase and excessive amounts of oxalyl chloride. The resulting crude was redissolved in dry dichloromethane $(10 \mathrm{~mL})$, and then slowly added into a solution of arylamine (30 mmol) or 4-arylthiazol-2-amine $(20 \mathrm{mmol})$ and triethylamine $(20 \mathrm{mmol})$ in dry dichloromethane $(20 \mathrm{~mL})$. The mixture was stirred at room temperature. After $12 \mathrm{~h}$, the mixture was washed by $10 \%$ hydrochloric acid $(3 \times, 10 \mathrm{~mL})$, water $(3 \times, 10 \mathrm{~mL})$, and brine $(10 \mathrm{~mL})$, dried over sodium sulfate, filtered, and concentrated under vacuum to afford crude products. The crude products were recrystallized from ethanol to afford compound $\mathbf{4 a - 4 1}$. The characterization data of compound $\mathbf{4 a - 4 1}$ were shown in Table 4. 
Table 4. Characterization data of $N$-ary-myrtanyl acid amides and $N$-(4-phenyl-thiazolyl-2-yl)-myrtanyl acid amides.

\begin{tabular}{|c|c|}
\hline Compound & Characterization Data \\
\hline $4 a$ & 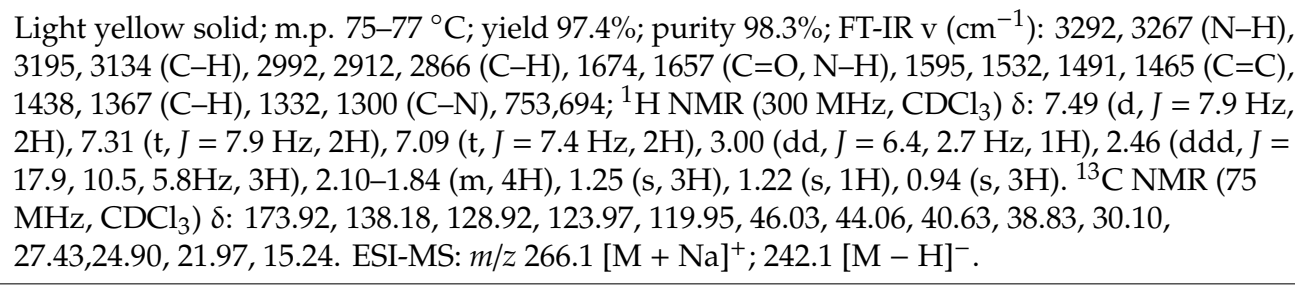 \\
\hline $4 b$ & 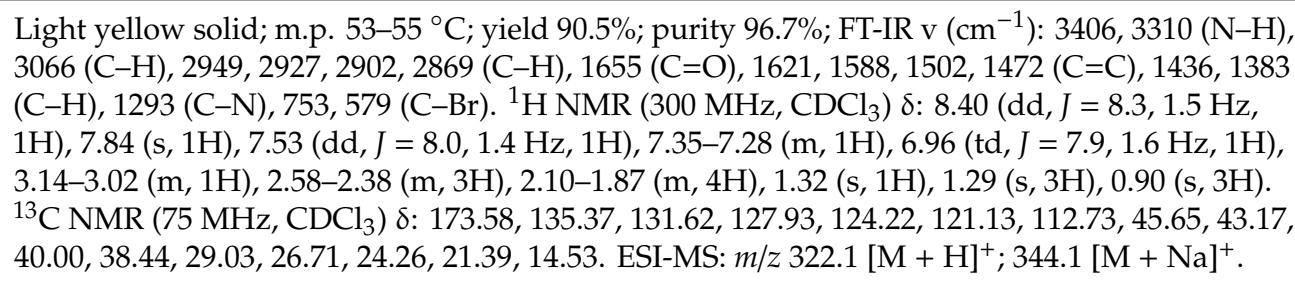 \\
\hline $4 c$ & 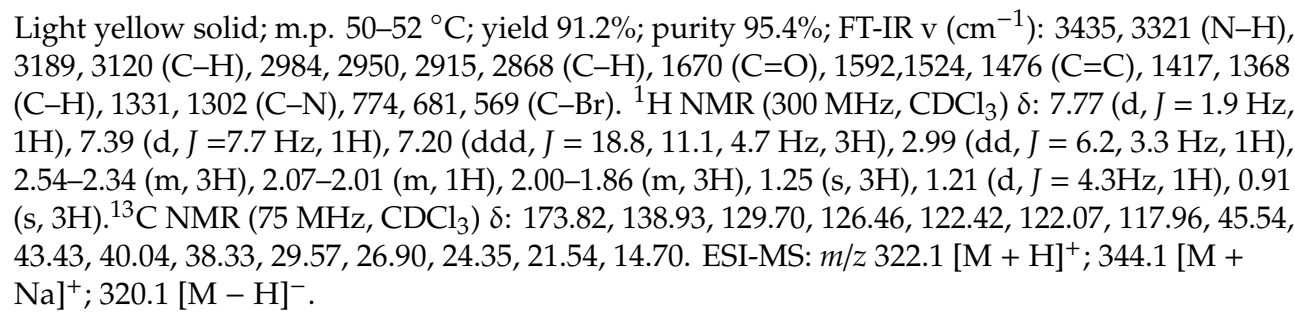 \\
\hline $4 d$ & $\begin{array}{l}\text { Yellow solid; m.p. } 84-86{ }^{\circ} \mathrm{C} \text {; yield 96.1\%; purity 98.7\%; FT-IR v }\left(\mathrm{cm}^{-1}\right): 3288,3253(\mathrm{~N}-\mathrm{H}), 3184, \\
3114,3037(\mathrm{C}-\mathrm{H}), 2987,2962,2914,2865(\mathrm{C}-\mathrm{H}), 1656(\mathrm{C}=\mathrm{O}), 1595,1514,1462(\mathrm{C}=\mathrm{C}), 1410,1382, \\
\left.1367(\mathrm{C}-\mathrm{H}), 1329,1298(\mathrm{C}-\mathrm{N}), 826 .{ }^{1} \mathrm{H} \mathrm{NMR}(300 \mathrm{MHz}, \mathrm{CDCl})_{3}\right) \delta: 7.40(\mathrm{~d}, J=8.4 \mathrm{~Hz}, 2 \mathrm{H}), 7.27 \\
(\mathrm{t}, J=9.6 \mathrm{~Hz}, 1 \mathrm{H}), 7.13(\mathrm{~d}, J=8.3 \mathrm{~Hz}, 2 \mathrm{H}), 3.04-2.90(\mathrm{~m}, 1 \mathrm{H}), 2.61(\mathrm{q}, J=7.6 \mathrm{~Hz}, 2 \mathrm{H}), 2.46(\mathrm{ddd}, J \\
=23.4,11.7,5.9 \mathrm{~Hz}, 3 \mathrm{H}), 2.08-1.81(\mathrm{~m}, 4 \mathrm{H}), 1.27-1.18(\mathrm{~m}, 7 \mathrm{H}), 0.94(\mathrm{~s}, 3 \mathrm{H}) .{ }^{13} \mathrm{C} \mathrm{NMR}(75 \mathrm{MHz}, \\
\left.\mathrm{CDCl}_{3}\right) \delta: 173.84,140.00,135.83,128.19,120.13,45.92,44.08,40.64,38.82,30.10,28.25,27.44, \\
24.92,21.97,15.63,15.25 . \text { ESI-MS: } \mathrm{m} / z 294.1\left[\mathrm{M}+\mathrm{Na}^{+} ; 270.1[\mathrm{M}-\mathrm{H}]^{-} .\right.\end{array}$ \\
\hline $4 e$ & $\begin{array}{l}\text { Yellow solid; m.p. 107-109 }{ }^{\circ} \mathrm{C} \text {; yield 94.4\%; purity 97.3\%; FT-IR v }\left(\mathrm{cm}^{-1}\right): 3301(\mathrm{~N}-\mathrm{H}), 3198, \\
3128(\mathrm{C}-\mathrm{H}), 2984,2953,2912,2866(\mathrm{C}-\mathrm{H}), 1670(\mathrm{C}=\mathrm{O}), 1601,1524,1464(\mathrm{C}=\mathrm{C}), 1407,1384,1367 \\
(\mathrm{C}-\mathrm{H}), 1320(\mathrm{C}-\mathrm{N}), 837 .{ }^{1} \mathrm{H} \mathrm{NMR}(300 \mathrm{MHz}, \mathrm{CDCl}) \mathrm{\delta}: 7.62(\mathrm{~d}, \mathrm{~J}=8.7 \mathrm{~Hz}, 2 \mathrm{H}), 7.55(\mathrm{~d}, J=8.7 \\
\mathrm{Hz}, 2 \mathrm{H}), 7.32(\mathrm{~s}, 1 \mathrm{H}), 3.01(\mathrm{dd}, J=6.3,2.6 \mathrm{~Hz}, 1 \mathrm{H}), 2.55-2.37(\mathrm{~m}, 3 \mathrm{H}), 2.08-1.88(\mathrm{~m}, 4 \mathrm{H}), 1.25(\mathrm{~s}, \\
3 \mathrm{H}), 1.21(\mathrm{~d}, J=2.1 \mathrm{~Hz}, 1 \mathrm{H}), 0.92(\mathrm{~s}, 3 \mathrm{H}) .{ }^{13} \mathrm{C} \mathrm{NMR}\left(75 \mathrm{MHz}, \mathrm{CDCl}_{3}\right) \delta: 175.16,142.15,127.18, \\
120.29,47.16,44.98,41.53,39.82,31.00,28.35,25.77,22.90,16.13 . \mathrm{ESI}-\mathrm{MS}: \mathrm{m} / z 334.1\left[\mathrm{M}+\mathrm{Na}^{+}\right]^{+} \\
310.1[\mathrm{M}-\mathrm{H}]^{-} .\end{array}$ \\
\hline $4 \mathrm{f}$ & $\begin{array}{l}\text { Yellow solid; m.p. } 107-109{ }^{\circ} \mathrm{C} \text {; yield } 88.2 \% \text {; purity 95.4\%; FT-IR v }\left(\mathrm{cm}^{-1}\right): 3328,3310(\mathrm{~N}-\mathrm{H}), \\
\text { 2987, } 2948,2917,2867(\mathrm{C}-\mathrm{H}), 1677,1659(\mathrm{C}=\mathrm{O}), 1622,1597,1510,1465(\mathrm{C}=\mathrm{C}), 1385,1366(\mathrm{C}-\mathrm{H}), \\
1288(\mathrm{C}-\mathrm{N}), 1006(\mathrm{C}-\mathrm{F}), 776,702 .{ }^{1} \mathrm{H} \mathrm{NMR}\left(300 \mathrm{MHz}, \mathrm{CDCl}_{3}\right) \delta: 7.14(\mathrm{~s}, 1 \mathrm{H}), 6.96-6.79(\mathrm{~m}, 3 \mathrm{H}), \\
3.05(\mathrm{~s}, 1 \mathrm{H}), 2.42(\mathrm{~d}, J=20.8 \mathrm{~Hz}, 3 \mathrm{H}), 1.95(\mathrm{dd}, J=45.4,21.0 \mathrm{~Hz}, 4 \mathrm{H}), 1.24(\mathrm{~s}, 4 \mathrm{H}), 0.94(\mathrm{~s}, 3 \mathrm{H}) \text {. } \\
{ }^{13} \mathrm{C} \mathrm{NMR}\left(75 \mathrm{MHz}, \mathrm{CDCl}_{3}\right) \delta: 174.16,172.21,158.88,156.89,127.13,114.41,111.52,111.37,45.27, \\
44.03,42.91,40.52,40.30,38.81,29.94,29.11,27.26,26.87,24.83,24.49,21.71,15.05 . \text { ESI-MS: } \mathrm{m} / z \\
280.1[\mathrm{M}+\mathrm{H}]^{+} ; 302.1[\mathrm{M}+\mathrm{Na}]^{+} ; 278.1[\mathrm{M}-\mathrm{H}]^{-} .\end{array}$ \\
\hline $4 \mathrm{~g}$ & 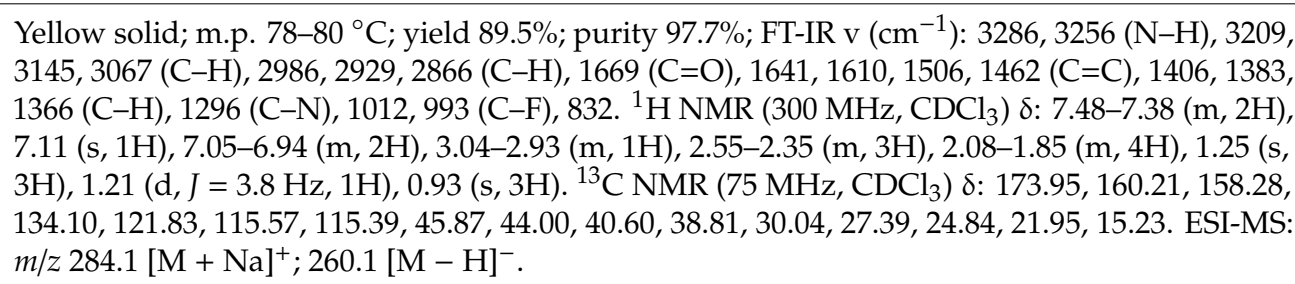 \\
\hline
\end{tabular}


Table 4. Cont.

\begin{tabular}{|c|c|}
\hline Compound & Characterization Data \\
\hline $4 h$ & $\begin{array}{l}\text { Yellow solid; m.p. } 103-105{ }^{\circ} \mathrm{C} \text {; yield } 84.4 \% \text {; purity } 96.2 \% \text {; FT-IR v }\left(\mathrm{cm}^{-1}\right): 3359(\mathrm{~N}-\mathrm{H}), 3117, \\
3084(\mathrm{C}-\mathrm{H}), 2987,2916,2868(\mathrm{C}-\mathrm{H}), 1703(\mathrm{C}=\mathrm{O}), 1609,1594,1540,1495,1463(\mathrm{C}=\mathrm{C}), 1405,1384, \\
1368(\mathrm{C}-\mathrm{H}), 1327(\mathrm{~N}=\mathrm{O}), 1296,1249(\mathrm{C}-\mathrm{N}), 854 .{ }^{1} \mathrm{H} \mathrm{NMR}\left(300 \mathrm{MHz}, \mathrm{CDCl}_{3}\right) \delta: 8.17(\mathrm{~d}, J=9.1 \\
\mathrm{Hz}, 2 \mathrm{H}), 7.69(\mathrm{~d}, J=9.2 \mathrm{~Hz}, 2 \mathrm{H}), 7.66(\mathrm{~d}, J=3.2 \mathrm{~Hz}, 1 \mathrm{H}), 3.03(\mathrm{dd}, J=5.9,2.6 \mathrm{~Hz}, 1 \mathrm{H}), 2.43(\mathrm{dt}, J \\
=12.4,6.3 \mathrm{~Hz}, 3 \mathrm{H}), 2.07-1.87(\mathrm{~m}, 4 \mathrm{H}), 1.23(\mathrm{~s}, 3 \mathrm{H}), 1.20(\mathrm{~d}, J=4.0 \mathrm{~Hz}, 1 \mathrm{H}), 0.95-0.82(\mathrm{~m}, 3 \mathrm{H}) . \\
{ }^{13} \mathrm{C} \mathrm{NMR}(75 \mathrm{MHz}, \mathrm{CDCl} 3) \delta: 175.50,145.16,144.19,125.99,120.01,47.42,46.32,44.93,43.90, \\
41.38,39.79,31.13,30.06,28.33,27.85,25.75,25.46,22.86,16.05 . \mathrm{ESI}-\mathrm{MS}: \mathrm{m} / z 311.1\left[\mathrm{M}+\mathrm{Na}^{+} ;\right. \\
287.1[\mathrm{M}-\mathrm{H}]^{-} .\end{array}$ \\
\hline $4 i$ & 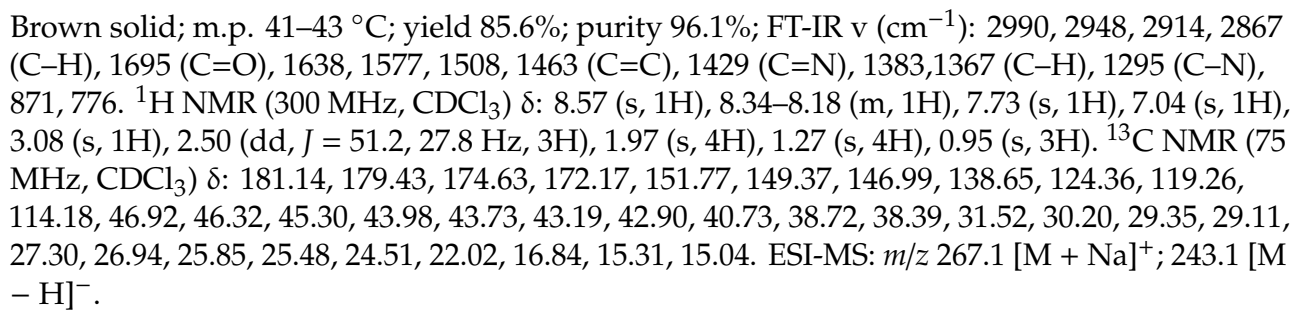 \\
\hline $4 j$ & 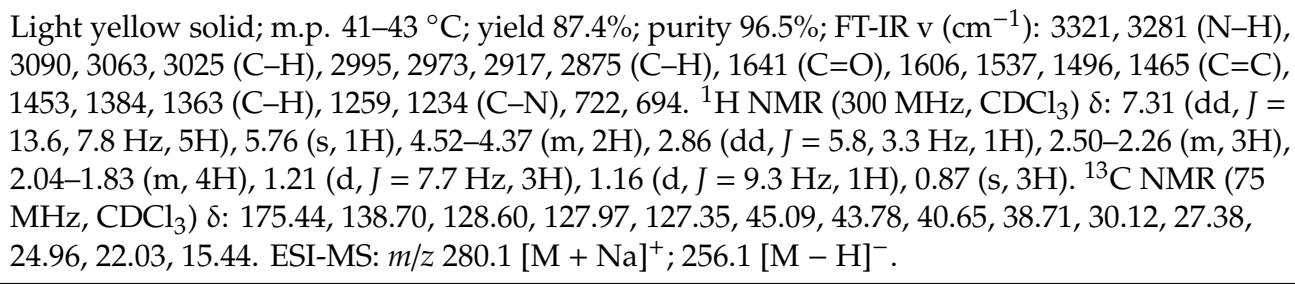 \\
\hline $4 k$ & $\begin{array}{l}\text { Scarlet solid; m.p. } 53-55^{\circ} \mathrm{C} \text {; yield 18.7\%; purity 95.5\%; FT-IR v }\left(\mathrm{cm}^{-1}\right): 3432(\mathrm{~N}-\mathrm{H}), 3192,3117, \\
3056(\mathrm{C}-\mathrm{H}), 2919,2869(\mathrm{C}-\mathrm{H}), 1687,1654(\mathrm{C}=\mathrm{O}), 1597,1539,1491,1465(\mathrm{C}=\mathrm{C}), 1410,1385,1368 \\
(\mathrm{C}-\mathrm{H}), 1321,1270(\mathrm{C}-\mathrm{N}), 1174,1156,1061(\mathrm{C}-\mathrm{S}-\mathrm{C}, \mathrm{C}-\mathrm{F}), 839 .{ }^{1} \mathrm{H} \mathrm{NMR}\left(300 \mathrm{MHz}, \mathrm{CDCl}_{3}\right) \delta: \\
11.91(\mathrm{~s}, 1 \mathrm{H}), 7.74(\mathrm{dd}, J=8.8,5.2 \mathrm{~Hz}, 1 \mathrm{H}), 7.64-7.30(\mathrm{~m}, 2 \mathrm{H}), 7.14(\mathrm{t}, J=8.7 \mathrm{~Hz}, 1 \mathrm{H}), 7.02(\mathrm{~s}, 1 \mathrm{H}), \\
3.24-3.12(\mathrm{~m}, 1 \mathrm{H}), 2.54(\mathrm{~s}, 1 \mathrm{H}), 2.48-2.36(\mathrm{~m}, 1 \mathrm{H}), 2.31(\mathrm{~s}, 1 \mathrm{H}), 2.10-1.83(\mathrm{~m}, 4 \mathrm{H}), 1.27(\mathrm{~s}, 1 \mathrm{H}), \\
1.23(\mathrm{~s}, 3 \mathrm{H}), 0.85(\mathrm{~s}, 3 \mathrm{H}) .{ }^{13} \mathrm{C} \mathrm{NMR}(75 \mathrm{MHz}, \mathrm{CDCl} 3) \delta: 173.66,163.81,160.52,158.91,148.09, \\
130.05,127.36,115.40,115.12,106.80,44.60,42.94,39.90,38.09,31.44,30.98,29.69,29.24,28.78, \\
26.58,24.08,22.21,21.27,13.78 . \mathrm{ESI}-\mathrm{MS}: \mathrm{m} / \mathrm{z} 345.1[\mathrm{M}+\mathrm{H}]^{+} ; 343.1[\mathrm{M}-\mathrm{H}]^{-} .\end{array}$ \\
\hline 41 & $\begin{array}{l}\text { Yellow solid; m.p. } 64-66^{\circ} \mathrm{C} \text {; yield 20.9\%; purity 96.6\%; FT-IR v }\left(\mathrm{cm}^{-1}\right): 3434(\mathrm{~N}-\mathrm{H}), 3117,3045 \\
(\mathrm{C}-\mathrm{H}), 2945,2916,2870,2837(\mathrm{C}-\mathrm{H}), 1687(\mathrm{C}=\mathrm{O}), 1612,1540,1492,1463(\mathrm{C}=\mathrm{C}), 1440,1419,1385, \\
1367(\mathrm{C}-\mathrm{H}), 1326,1285,1249(\mathrm{C}-\mathrm{N}), 1173,1110,1062(\mathrm{C}-\mathrm{S}-\mathrm{C}), 834 .{ }^{1} \mathrm{H} \text { NMR }\left(300 \mathrm{MHz}, \mathrm{CDCl}_{3}\right) \\
\delta: 11.04(\mathrm{~s}, 1 \mathrm{H}), 7.72(\mathrm{dq}, J=4.5,1.8 \mathrm{~Hz}, 2 \mathrm{H}), 7.03-6.89(\mathrm{~m}, 3 \mathrm{H}), 3.85(\mathrm{~s}, 3 \mathrm{H}), 3.19-3.11(\mathrm{~m}, 1 \mathrm{H}), \\
2.60-2.53(\mathrm{~m}, 1 \mathrm{H}), 2.49-2.38(\mathrm{~m}, 2 \mathrm{H}), 2.09-1.89(\mathrm{~m}, 4 \mathrm{H}), 1.25(\mathrm{~s}, 3 \mathrm{H}), 1.23(\mathrm{~s}, 1 \mathrm{H}), 0.85(\mathrm{~s}, 3 \mathrm{H}) . \\
{ }^{13} \mathrm{C} \mathrm{NMR}(75 \mathrm{MHz}, \mathrm{CDCl} 3) \delta: 174.68,165.59,164.21,131.99,126.84,113.68(\mathrm{~s}), 112.44,105.36, \\
54.86,44.63,42.88,39.95,29.24,26.60,25.82,24.13,21.29,14.15 . \mathrm{ESI}-\mathrm{MS}: \mathrm{m} / \mathrm{z} 357.1[\mathrm{M}+\mathrm{H}]^{+} ; \\
355.1[\mathrm{M}-\mathrm{H}]^{-} .\end{array}$ \\
\hline
\end{tabular}

\subsubsection{Synthesis of Myrtanyl Acid Acylthiourea Derivative (Compounds $\mathbf{4 m - 4 t )}$}

A solution of myrtanyl acid $(20 \mathrm{mmol})$ and oxalyl chloride $(30 \mathrm{mmol})$ in dry dichloromethane $(20 \mathrm{~mL})$ was stirred at $50^{\circ} \mathrm{C}$ for $4 \mathrm{~h}$. Then, the reaction mixture was evaporated under reduced pressure to remove the organic phase and excessive amounts of oxalyl chloride. The resulting crude was redissolved in dry acetonitrile $(10 \mathrm{~mL})$, then slowly added into a solution of potassium thiocyanate (30 mmol) in dry acetonitrile $(30 \mathrm{~mL})$. The mixture then was stirred at room temperature. After $12 \mathrm{~h}$, a solution of arylamine $(30 \mathrm{mmol})$ or 4-arylthiazol-2-amine $(20 \mathrm{mmol})$ in dry acetonitrile $(30 \mathrm{~mL})$ was added into the mixture. The mixture was stirred at $80^{\circ} \mathrm{C}$. After $8 \mathrm{~h}$, the mixture was filtered, evaporated under reduced pressure to remove the organic phase and recrystallized from ethanol to afford compounds $\mathbf{4 m - 4 t}$. The characterization data of compound $\mathbf{4 m - 4 t}$ were shown in Table 5 . 
Table 5. Characterization data of $N$-aryl- $N^{\prime}$-myrtanyl acylthiourea and $N$-(4-arylthiazol-2-yl)$N^{\prime}$-myrtanylacylthiourea.

\begin{tabular}{|c|c|}
\hline Compound & Characterization Data \\
\hline $4 \mathrm{~m}$ & $\begin{array}{l}\text { Light yellow solid; m.p. } 85-87^{\circ} \mathrm{C} \text {; yield 82.4\%; purity 96.4\%; FT-IR v }\left(\mathrm{cm}^{-1}\right): 3635(\mathrm{~N}-\mathrm{H}), 3164,3028 \\
(\mathrm{C}-\mathrm{H}), 2987,2915,2868(\mathrm{C}-\mathrm{H}), 1686(\mathrm{C}=\mathrm{O}), 1563(\mathrm{~N}-\mathrm{H}), 1598,1516,1498,1469(\mathrm{C}=\mathrm{C}), 1447,1384,1356 \\
(\mathrm{C}-\mathrm{H}), 1327,1310,1296(\mathrm{C}-\mathrm{N}), 1238(\mathrm{C}-\mathrm{O}), 1143,1102(\mathrm{C}=\mathrm{S}), 756,685 .{ }^{1} \mathrm{H} \mathrm{NMR}\left(300 \mathrm{MHz}, \mathrm{CDCl}_{3}\right) \delta: \\
12.47(\mathrm{~s}, 1 \mathrm{H}), 8.55(\mathrm{~s}, 1 \mathrm{H}), 7.72(\mathrm{~d}, J=8.0 \mathrm{~Hz}, 2 \mathrm{H}), 7.44(\mathrm{t}, J=7.8 \mathrm{~Hz}, 2 \mathrm{H}), 7.35-7.29(\mathrm{~m}, 1 \mathrm{H}), 3.10-3.00(\mathrm{~m}, \\
1 \mathrm{H}), 2.53-2.44(\mathrm{~m}, 2 \mathrm{H}), 2.41(\mathrm{ddd}, J=13.8,6.9,3.6 \mathrm{~Hz}, 1 \mathrm{H}), 2.13-1.93(\mathrm{~m}, 4 \mathrm{H}), 1.32(\mathrm{~s}, 3 \mathrm{H}), 1.25(\mathrm{~d}, J=9.7 \\
\mathrm{Hz}, 1 \mathrm{H}), 0.97(\mathrm{~s}, 3 \mathrm{H}) .{ }^{13} \mathrm{C} \mathrm{NMR}\left(126 \mathrm{MHz}, \mathrm{CDCl}_{3}\right) \delta: 178.33,176.81,137.66,129.25,128.78,126.69,123.95, \\
46.22,43.27,40.36,38.75,30.00,27.15,24.61,22.03,14.81 . \mathrm{ESI}-\mathrm{MS}: \mathrm{m} / \mathrm{z} 325.1[\mathrm{M}+\mathrm{Na}]^{+} ; 301.2[\mathrm{M}-\mathrm{H}]^{-} .\end{array}$ \\
\hline $4 n$ & $\begin{array}{l}\text { Light yellow solid; m.p. } 116-118^{\circ} \mathrm{C} \text {; yield 80.7\%; purity 96.9\%; FT-IR v }\left(\mathrm{cm}^{-1}\right): 3300(\mathrm{~N}-\mathrm{H}), 3141,3002 \\
(\mathrm{C}-\mathrm{H}), 2943,2918,2865(\mathrm{C}-\mathrm{H}), 1681(\mathrm{C}=\mathrm{O}), 1516(\mathrm{~N}-\mathrm{H}), 1576,1467(\mathrm{C}=\mathrm{C}), 1442,1382,1366(\mathrm{C}-\mathrm{H}), 1332, \\
1309,1285(\mathrm{C}-\mathrm{N}), 1238(\mathrm{C}-\mathrm{O}), 1159,1122(\mathrm{C}=\mathrm{S}), 744 .{ }^{1} \mathrm{H} \mathrm{NMR}(300 \mathrm{MHz}, \mathrm{CDCl} 3) \delta: 12.45(\mathrm{~s}, 1 \mathrm{H}), 8.68(\mathrm{~s}, \\
1 \mathrm{H}), 8.22(\mathrm{~d}, J=8.1 \mathrm{~Hz}, 1 \mathrm{H}), 7.68(\mathrm{~d}, J=8.0 \mathrm{~Hz}, 1 \mathrm{H}), 7.41(\mathrm{t}, J=7.7 \mathrm{~Hz}, 1 \mathrm{H}), 7.19(\mathrm{t}, J=7.7 \mathrm{~Hz}, 1 \mathrm{H}), 3.07 \\
(\mathrm{~d}, J=7.6 \mathrm{~Hz}, 1 \mathrm{H}), 2.52-2.41(\mathrm{~m}, 3 \mathrm{H}), 2.13-1.92(\mathrm{~m}, 4 \mathrm{H}), 1.32(\mathrm{~s}, 3 \mathrm{H}), 1.27(\mathrm{~d}, J=7.7 \mathrm{~Hz}, 1 \mathrm{H}), 0.98(\mathrm{~s}, 3 \mathrm{H}) . \\
{ }^{13} \mathrm{C} \mathrm{NMR}(126 \mathrm{MHz}, \mathrm{CDCl} 3) \delta: 179.20,176.60,136.52,132.86,128.13,127.37,118.66,46.11,43.37,40.38, \\
38.84,29.84,27.18,24.56,21.93,14.65 . \text { ESI-MS: } \mathrm{m} / \mathrm{z} 403.0\left[\mathrm{M}+\mathrm{Na}^{+} ; 379.1[\mathrm{M}-\mathrm{H}]^{-} .\right.\end{array}$ \\
\hline 40 & $\begin{array}{l}\text { Light yellow solid; m.p. 89-91 }{ }^{\circ} \mathrm{C} \text {; yield } 81.3 \% \text {; purity 97.2\%; FT-IR v }\left(\mathrm{cm}^{-1}\right): 3295(\mathrm{~N}-\mathrm{H}), 3161,3004 \\
(\mathrm{C}-\mathrm{H}), 2965,2922,2862(\mathrm{C}-\mathrm{H}), 1687,1657(\mathrm{C}=\mathrm{O}), 1518(\mathrm{~N}-\mathrm{H}), 1588,1462(\mathrm{C}=\mathrm{C}), 1412,1384(\mathrm{C}-\mathrm{H}), 1327 \\
(\mathrm{C}-\mathrm{N}), 1249(\mathrm{C}-\mathrm{O}), 1155,1136(\mathrm{C}=\mathrm{S}), 835 .{ }^{1} \mathrm{H} \mathrm{NMR}\left(300 \mathrm{MHz}, \mathrm{CDCl}_{3}\right) \delta: 12.37(\mathrm{~s}, 1 \mathrm{H}), 8.47(\mathrm{~s}, 1 \mathrm{H}), 7.61 \\
(\mathrm{~d}, J=8.1 \mathrm{~Hz}, 2 \mathrm{H}), 7.31(\mathrm{~s}, 1 \mathrm{H}), 7.26(\mathrm{~s}, 1 \mathrm{H}), 3.05(\mathrm{~s}, 1 \mathrm{H}), 2.70(\mathrm{q}, J=7.5 \mathrm{~Hz}, 2 \mathrm{H}), 2.48(\mathrm{dd}, J=14.1,6.9 \mathrm{~Hz} \text {, } \\
2 \mathrm{H}), 2.39(\mathrm{~d}, J=9.8 \mathrm{~Hz}, 1 \mathrm{H}), 2.02(\mathrm{dd}, J=33.3,21.1 \mathrm{~Hz}, 5 \mathrm{H}), 1.32(\mathrm{~s}, 3 \mathrm{H}), 1.30(\mathrm{~d}, J=7.5 \mathrm{~Hz}, 3 \mathrm{H}), 1.28(\mathrm{~s}, \\
1 \mathrm{H}), 0.97(\mathrm{~s}, 3 \mathrm{H}) .{ }^{13} \mathrm{C} \mathrm{NMR}\left(126 \mathrm{MHz}, \mathrm{CDCl}_{3}\right) \delta: 178.26,176.70,142.94,135.27,128.19,123.99,46.21, \\
43.24,40.37,38.77,29.96,28.41,27.14,24.61,22.02,15.33,14.81 . \mathrm{ESI}-\mathrm{MS}: \mathrm{m} / z 331.2[\mathrm{M}+\mathrm{H}]^{+} ; 353.2[\mathrm{M}+ \\
\mathrm{Na}^{+} ; 329.1[\mathrm{M}-\mathrm{H}]^{-} .\end{array}$ \\
\hline $4 p$ & $\begin{array}{l}\text { Light yellow solid; m.p. 110-112 }{ }^{\circ} \mathrm{C} \text {; yield 83.3\%; purity 95.4\%; FT-IR v }\left(\mathrm{cm}^{-1}\right): 3247,3200(\mathrm{~N}-\mathrm{H}), 3017 \\
(\mathrm{C}-\mathrm{H}), 2999,2921,2870(\mathrm{C}-\mathrm{H}), 1700(\mathrm{C}=\mathrm{O}), 1524(\mathrm{~N}-\mathrm{H}), 1612,1596,1466(\mathrm{C}=\mathrm{C}), 1409,1387,1369(\mathrm{C}-\mathrm{H}), \\
1319(\mathrm{C}-\mathrm{N}), 1256(\mathrm{C}-\mathrm{O}), 1160,1122,1103(\mathrm{C}=\mathrm{S}), 1063,1015(\mathrm{C}-\mathrm{F}), 841 .{ }^{1} \mathrm{H} \mathrm{NMR}\left(300 \mathrm{MHz}, \mathrm{CDCl}_{3}\right) \delta: \\
12.73(\mathrm{~s}, 1 \mathrm{H}), 8.71(\mathrm{~s}, 1 \mathrm{H}), 7.92(\mathrm{~d}, J=8.2 \mathrm{~Hz}, 2 \mathrm{H}), 7.69(\mathrm{~d}, J=8.3 \mathrm{~Hz}, 2 \mathrm{H}), 3.07(\mathrm{dd}, J=6.0,3.1 \mathrm{~Hz}, 1 \mathrm{H}), \\
2.55-2.43(\mathrm{~m}, 2 \mathrm{H}), 2.39(\mathrm{t}, J=10.2 \mathrm{~Hz}, 1 \mathrm{H}), 2.12-1.93(\mathrm{~m}, 4 \mathrm{H}), 1.32(\mathrm{~s}, 3 \mathrm{H}), 1.25(\mathrm{~d}, J=9.9 \mathrm{~Hz}, 1 \mathrm{H}), 0.97(\mathrm{~s}, \\
\left.3 \mathrm{H}) .{ }^{13} \mathrm{C} \mathrm{NMR}(126 \mathrm{MHz}, \mathrm{CDCl})_{3}\right) \delta: 178.50,177.19,140.71,128.43,128.17,125.97,124.92,123.56,122.75, \\
46.29,43.52,43.33,40.34,38.74,30.11,27.16,24.60,22.07,14.83 . \text { ESI-MS: } \mathrm{m} / \mathrm{z} 371.1[\mathrm{M}+\mathrm{H}]^{+} ; 369.1[\mathrm{M}- \\
\mathrm{H}]^{-} .\end{array}$ \\
\hline $4 q$ & 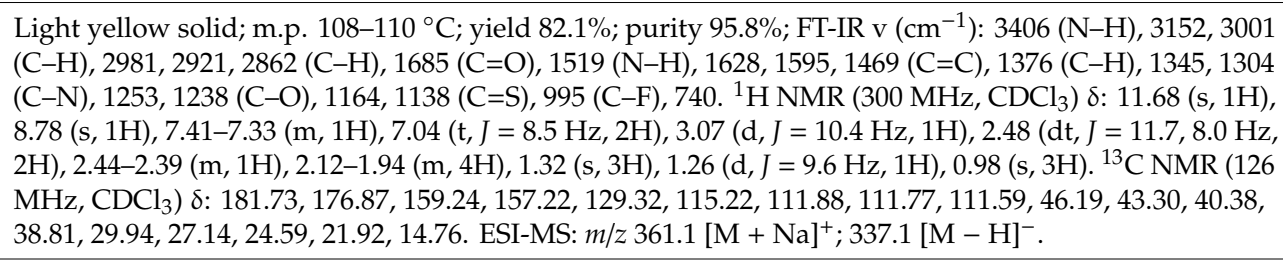 \\
\hline $4 \mathbf{r}$ & $\begin{array}{l}\text { Light yellow solid; m.p. } 92-94{ }^{\circ} \mathrm{C} \text {; yield } 81.9 \% \text {; purity 96.0\%; FT-IR v }\left(\mathrm{cm}^{-1}\right): 3638(\mathrm{~N}-\mathrm{H}), 3132,3028 \\
(\mathrm{C}-\mathrm{H}), 2986,2920,2866(\mathrm{C}-\mathrm{H}), 1687(\mathrm{C}=\mathrm{O}), 1524(\mathrm{~N}-\mathrm{H}), 1607,1505,1465(\mathrm{C}=\mathrm{C}), 1411,1385,1367 \mathrm{C}-\mathrm{H}), \\
1331(\mathrm{C}-\mathrm{N}), 1253(\mathrm{C}-\mathrm{O}), 1215,1151(\mathrm{C}=\mathrm{S}), 1010(\mathrm{C}-\mathrm{F}), 837 .{ }^{1} \mathrm{H} \mathrm{NMR}(300 \mathrm{MHz}, \mathrm{CDCl}) \delta: 12.39(\mathrm{~s}, 1 \mathrm{H}), \\
8.57(\mathrm{~s}, 1 \mathrm{H}), 7.66(\mathrm{dd}, J=8.7,4.7 \mathrm{~Hz}, 2 \mathrm{H}), 7.12(\mathrm{t}, J=8.5 \mathrm{~Hz}, 2 \mathrm{H}), 3.05(\mathrm{dd}, J=6.3,3.4 \mathrm{~Hz}, 1 \mathrm{H}), 2.48(\mathrm{dd}, J \\
=16.8,7.2 \mathrm{~Hz}, 2 \mathrm{H}), 2.43-2.36(\mathrm{~m}, 1 \mathrm{H}), 2.11-1.97(\mathrm{~m}, 4 \mathrm{H}), 1.32(\mathrm{~s}, 3 \mathrm{H}), 1.25(\mathrm{~d}, J=9.9 \mathrm{~Hz}, 1 \mathrm{H}), 0.97(\mathrm{~s}, 3 \mathrm{H}) . \\
{ }^{13} \mathrm{C} \mathrm{NMR}\left(126 \mathrm{MHz}, \mathrm{CDCl}_{3}\right) \delta: 179.16,178.87,176.92,161.87,159.91,133.67,126.05,115.74,115.56,46.24, \\
43.92,43.28,40.35,39.92,38.76,30.02,27.15,26.27,24.61,23.91,23.56,22.05,20.17,16.16,14.83 . \text { ESI-MS: } \\
m / z 343.1\left[\mathrm{M}+\mathrm{Na}^{+} ; 319.1[\mathrm{M}-\mathrm{H}]^{-} .\right.\end{array}$ \\
\hline $4 s$ & $\begin{array}{l}\text { Light yellow solid; m.p. } 172-174{ }^{\circ} \mathrm{C} \text {; yield 9.7\%; purity 90.9\%; FT-IR v }\left(\mathrm{cm}^{-1}\right): 3603(\mathrm{~N}-\mathrm{H}), 3245,3187, \\
3007(\mathrm{C}-\mathrm{H}), 2942,2917,2870(\mathrm{C}-\mathrm{H}), 1697(\mathrm{C}=\mathrm{O}), 1531(\mathrm{~N}-\mathrm{H}), 1546,1484(\mathrm{C}=\mathrm{C}), 1449,1412,1386(\mathrm{C}-\mathrm{H}), \\
1309,1293(\mathrm{C}-\mathrm{N}), 1277(\mathrm{C}-\mathrm{O}), 1226,1209,1158,1126(\mathrm{C}=\mathrm{S}), 1062(\mathrm{C}-\mathrm{S}-\mathrm{C}), 1012(\mathrm{C}-\mathrm{F}), 837 .{ }^{1} \mathrm{H} \mathrm{NMR}(300 \\
\left.\mathrm{MHz}, \mathrm{CDCl}_{3}\right) \delta: 13.75(\mathrm{~s}, 1 \mathrm{H}), 8.49(\mathrm{~s}, 1 \mathrm{H}), 7.87(\mathrm{dd}, J=8.5,5.4 \mathrm{~Hz}, 2 \mathrm{H}), 7.11(\mathrm{dd}, J=14.3,5.6 \mathrm{~Hz}, 3 \mathrm{H}), \\
3.05(\mathrm{dd}, J=6.6,3.6 \mathrm{~Hz}, 1 \mathrm{H}), 2.44(\mathrm{ddd}, J=20.7,15.9,9.3 \mathrm{~Hz}, 3 \mathrm{H}), 2.10-1.92(\mathrm{~m}, 4 \mathrm{H}), 1.29(\mathrm{~s}, 3 \mathrm{H}), 1.25(\mathrm{~d}, \\
J=9.8 \mathrm{~Hz}, 1 \mathrm{H}), 0.93(\mathrm{~s}, 3 \mathrm{H}) .{ }^{13} \mathrm{C} \mathrm{NMR}(126 \mathrm{MHz}, \mathrm{CDCl}) \text { ) } 8: 176.57,174.90,158.50,149.69,127.86,115.66, \\
115.49,107.60,46.24,43.25,40.33,38.86,29.86,27.13,24.55,22.02,14.73 . \mathrm{ESI}-\mathrm{MS}: \mathrm{m} / z 404.1[\mathrm{M}+\mathrm{H}]^{+} ; \\
426.1\left[\mathrm{M}+\mathrm{Na}^{+} ; 402.1[\mathrm{M}-\mathrm{H}]^{-} .\right.\end{array}$ \\
\hline $4 t$ & $\begin{array}{l}\text { Light yellow solid; m.p. } 221-223{ }^{\circ} \mathrm{C} \text {; yield 8.4\%; purity 93.2\%; FT-IR v }\left(\mathrm{cm}^{-1}\right): 3418(\mathrm{~N}-\mathrm{H}), 3252,3197 \\
(\mathrm{C}-\mathrm{H}), 2942,2921,2870(\mathrm{C}-\mathrm{H}), 1699(\mathrm{C}=\mathrm{O}), 1527(\mathrm{~N}-\mathrm{H}), 1600,1545,1515,1477(\mathrm{C}=\mathrm{C}), 1446,1412,1385 \\
(\mathrm{C}-\mathrm{H}), 1342(\mathrm{~N}=\mathrm{O}), 1316,1300(\mathrm{C}-\mathrm{N}), 1283(\mathrm{C}-\mathrm{O}), 1209,1166,1127,1107(\mathrm{C}=\mathrm{S}), 1061(\mathrm{C}-\mathrm{S}-\mathrm{C}), 856,730 . \\
{ }^{1} \mathrm{H} \mathrm{NMR}\left(300 \mathrm{MHz}, \mathrm{CDC}_{3}\right) \delta: 13.81(\mathrm{~s}, 1 \mathrm{H}), 8.57(\mathrm{~s}, 1 \mathrm{H}), 8.27(\mathrm{~d}, J=8.7 \mathrm{~Hz}, 2 \mathrm{H}), 8.04(\mathrm{~d}, J=8.7 \mathrm{~Hz}, 2 \mathrm{H}), \\
7.38(\mathrm{~s}, 1 \mathrm{H}), 3.12-3.03(\mathrm{~m}, 1 \mathrm{H}), 2.52-2.37(\mathrm{~m}, 3 \mathrm{H}), 2.02(\mathrm{ddd}, J=27.5,21.0,14.2 \mathrm{~Hz}, 4 \mathrm{H}), 1.29(\mathrm{~s}, 3 \mathrm{H}), 1.25 \\
(\mathrm{~d}, J=9.8 \mathrm{~Hz}, 1 \mathrm{H}), 0.94(\mathrm{~s}, 3 \mathrm{H}) .{ }^{13} \mathrm{C} \mathrm{NMR}\left(126 \mathrm{MHz}, \mathrm{CDCl}_{3}\right) \delta: 176.81,175.24,159.03,148.21,147.28, \\
139.96,126.62,124.11,111.28,46.27,43.24,40.29,38.83,29.89,27.12,24.53,22.03,14.73 . \text { ESI-MS: } \mathrm{m} / \mathrm{z} 453.2 \\
{\left[\mathrm{M}+\mathrm{Na}^{+} ; 429.1[\mathrm{M}-\mathrm{H}]^{-} .\right.}\end{array}$ \\
\hline
\end{tabular}




\subsection{Biological Activity Evaluation}

The mycelial growth rate method was used to determine the inhibitory effect of $\beta$-pinene-based derivatives at serial concentration gradient on the mycelial growth of Colletotrichum gloeosporioides, Fusarium proliferatum, Alternaria kikuchiana, Phomopsis sp. and Phytophthora capsici. A certain mass of the $\beta$-pinene-based derivatives was weighed, dissolved in a small amount of methanol, and made up into a mother liquor of $28,000 \mu \mathrm{mol} / \mathrm{L}$ with sterile water. Then, a certain amount of mother liquor was pipetted into the PDA medium, in order to formulate the PDA medium containing $\beta$-pinene-based derivatives at concentrations of $500 \mu \mathrm{mol} / \mathrm{L}, 250 \mu \mathrm{mol} / \mathrm{L}, 125 \mu \mathrm{mol} / \mathrm{L}, 62.5 \mu \mathrm{mol} / \mathrm{L}, 31.25 \mu \mathrm{mol} / \mathrm{L}$. The PDA medium of methanol/sterile water solution was used as a negative control, and carbendazim was used as a positive control. All the tests were repeated three times. Finally, the PDA mediums were cultured in a $25 \pm 2{ }^{\circ} \mathrm{C}$ light incubator. The growth inhibition effects were measured when the fungus cake of the negative control plate was grown to about two-thirds of the whole culture dish. Cross method was applied to measure the diameter of the fungus cake, and the growth inhibition ratio was calculated by Equations (1) and (2). The $\mathrm{IC}_{50}$ value was calculated by using the SPSS procedure PROBIT.

$$
\begin{gathered}
\text { Corrected diameter }(\mathrm{cm})=\text { average diameter of colonies }(\mathrm{cm})-\text { diameter of fungus } \\
\text { cake }(0.5 \mathrm{~cm})
\end{gathered}
$$

Inhibition rate $(\%)=[$ control corrected diameter $(\mathrm{cm})-$ treatment corrected diameter $(\mathrm{cm})] /$ control corrected diameter $(\mathrm{cm}) \times 100 \%$

\section{Conclusions}

In this study, a series of pinene-based amide derivatives and acylthiourea derivatives were synthesized by using molecular structure design and organic synthesis methods. The mycelial growth rate method was used to determine the inhibitory effect of $\beta$-pinene-based derivatives at serial concentration gradient on the mycelial growth of Colletotrichum gloeosporioides, Fusarium proliferatum, Alternaria kikuchiana, Phomopsis sp. and Phytophthora capsici. The results show that $\beta$-pinene-based derivatives that were synthesized by the blend of amide group and pinane skeleton or the blend of acylthiourea group and pinane skeleton exerted better antifungal activity against plant pathogens. Some derivatives exhibited moderate to significant antifungal activity. The structure-activity relationship analysis showed that fluorine atoms and strong electron withdrawing groups (nitro groups or trifluoromethyl groups) on the benzene ring of the derivatives have a significant influence on the improvement of the antifungal activity against Colletotrichum gloeosporioides, Fusarium proliferatum, Alternaria kikuchiana and Phomopsis sp. Meanwhile, the introduction of ethyl groups at the meta-position on the benzene ring of the derivatives could improve the antifungal activity against Phytophthora capsici. Among these derivatives, the compounds $\mathbf{4 e}, \mathbf{4 h}, \mathbf{4 q}$ and $4 \mathbf{r}$ exhibited good and broad-spectrum antifungal activity. Compound 40 exhibited potent antifungal activity against Phytophthora capsici. These derivatives can be used as precursor molecules for further pesticides development.

Supplementary Materials: The following are available online: FTIR, NMR and MS spectra of all the derivatives.

Author Contributions: All authors conceived and designed the experiments; S.L. and Z.W. contributed reagents/ materials/analysis tools and directed the experiments; Y.S. and H.S. performed the experiments; Y.S., H.S. and S.L. analyzed the data; Y.S. and S.L. wrote the paper, P.W., S.C., S.S. and Z.S. revised the original manuscript. All authors gave their approval to the final version of the manuscript.

Funding: This work is supported by the National Natural Science Foundation of China (31800493), the National Key Research and Development Program of China during the 13th Five-Year Plan Period (2017YFD0600704), and the Science and Technology Research Project of Jiangxi Provincial Department of Education (GJJ160364, GJJ170255).

Acknowledgments: The authors thank Fengjun Liu, Shaojun Xiong, Rui Zhou, Weiwei Jiang, Xiong Zheng, Shiwen Feng, for their kind help on antifungal activity evaluation.

Conflicts of Interest: The authors declare no conflict of interest. 


\section{References}

1. Knogge, W. Fungal infection of plants. Plant Cell 1996, 8, 1711. [CrossRef] [PubMed]

2. Mendgen, K.; Hahn, M. Plant infection and the establishment of fungal biotrophy. Trends Plant Sci. 2002, 7, 352-356. [CrossRef]

3. Bebber, D.P.; Gurr, S.J. Crop-destroying fungal and oomycete pathogens challenge food security. Fungal Genet. Biol. 2015, 74, 62-64. [CrossRef] [PubMed]

4. Carvalho, F.P. Pesticides, environment, and food safety. Food Energy Secur. 2017, 6, 48-60. [CrossRef]

5. Russell, P.E. A century of fungicide evolution. J. Agri. Sci. 2005, 143, 11-25. [CrossRef]

6. Fisher, M.C.; Hawkins, N.J.; Sanglard, D.; Gurr, S.J. Worldwide emergence of resistance to antifungal drugs challenges human health and food security. Science 2018, 360, 739-742. [CrossRef] [PubMed]

7. Robbins, N.; Caplan, T.; Cowen, L.E. Molecular evolution of antifungal drug resistance. Ann. Rev. Microbiol. 2017, 71, 753-775. [CrossRef] [PubMed]

8. Silva, A.C.R.; Lopes, P.M.; Azevedo, M.M.B.; Costa, D.C.M.; Alviano, C.S.; Alviano, D.S. Biological activities of a-pinene and $\beta$-pinene enantiomers. Molecules 2012, 17, 6305-6316. [CrossRef]

9. De Macêdo, A.; Cláudia, A.; Rosalen, P.L.; de Macêdo, A.; Cláudia, A.; Rosalen, P.L.; Freires, I.A.; Scotti, L.; Scotti, M.T.; Aquino, S.G.; et al. Antifungal activity, mode of action, docking prediction and anti-biofilm effects of (+)- $\beta$-pinene enantiomers against Candida spp. Curr. Top. Med. Chem. 2018, 18, 2481-2490. [CrossRef]

10. Wilson, C.L.; Solar, J.M.; El Ghaouth, A.; Wisniewski, M.E. Rapid evaluation of plant extracts and essential oils for antifungal activity against Botrytis cinerea. Plant Dis. 1997, 81, 204-210. [CrossRef]

11. Nikitina, L.E.; StartsevaI, V.A.; VakulenkoI, A.; Khismatulina, M.; Lisovskaya, S.A.; Glushko, N.P.; Fassakhov, R.S. Synthesis and antifungal activity of compounds of the pinene series. Pharm. Chem. J. 2009, 43, 251-254. [CrossRef]

12. Gavrilov, V.V.; Startseva, V.A.; Nikitina, L.E.; Lodochnikova, O.A.; Gnezdilov, O.I.; Lisovskaya, S.A.; Glushko, N.I.; Klimovitskii, E.N. Synthesis and antifungal activity of sulfides, sulfoxides, and sulfones based on (1S)-(-)- $\beta$-pinene. Pharm. Chem. J. 2010, 44, 126-129. [CrossRef]

13. Liao, S.; Shang, S.; Shen, M.; Rao, X.; Si, H.; Song, J.; Song, Z. One-pot synthesis and antimicrobial evaluation of novel 3-cyanopyridine derivatives of (-)- $\beta$-pinene. Bioorg. Med. Chem. Lett. 2016, 26, 1512-1515. [CrossRef] [PubMed]

14. Li, J.; Tian, X.; Gao, Y.; Shang, S.; Feng, J.; Zhang, X. A value-added use of volatile turpentine: Antifungal activity and QSAR study of $\beta$-pinene derivatives against three agricultural fungi. RSC Adv. 2015, 5, 66947-66955. [CrossRef]

15. Gao, Y.; Hao, J.; Li, J.; Song, Z.; Shang, S. Structural modification of turpentine with natural chiral preservation and low-risk application prospects in crop protection. ACS Omega 2019, 4, 6392-6398. [CrossRef]

16. Gao, Y.; Wang, Y.; Li, J.; Shang, S.; Song, Z. Improved application of natural forest product terpene for discovery of potential botanical fungicide. Ind. Crop. Prod. 2018, 126, 103-112. [CrossRef]

17. Gao, Y.; Li, J.; Li, J.; Song, Z.; Shang, S.; Rao, X. High add valued application of turpentine in crop production through structural modification and QSAR analysis. Molecules 2018, 23, 356. [CrossRef]

18. Antypenko, L.; Meyer, F.; Kholodniak, O.; Sadykova, Z.; JiráskovákovirvTroianova, A.; Buhaiova, V.; Cao, S.; Kovalenko, S.; Garbe, L.A.; Steffens, K.G. Novel acyl thiourea derivatives: Synthesis, antifungal activity, gene toxicity, drug-like and molecular docking screening. ARCH Pham. 2019, 352, 1800275. [CrossRef]

19. Qin, Y.; Liu, W.; Xing, R.; Liu, S.; Li, K.; Li, P. Cyclization reaction of acyl thiourea chitosan: Enhanced antifungal properties via structural optimization. Molecules 2018, 23, 594. [CrossRef]

20. Liu, J.; He, L.; Zhou, G. Specific and rapid detection of Camellia oleifera anthracnose pathogen by nested-PCR. Afr. J. Biotechnol. 2009, 8, 1056-1061.

21. Huang, S.; Wang, L.; Liu, L.; Tang, S.; Zhu, D.; Savary, S. Rice spikelet rot disease in China- 1. Characterization of fungi associated with the disease. Crop. Prot. 2011, 30, 1-9. [CrossRef]

22. Masratul Hawa, M.; Salleh, B.; Latiffah, Z. Characterization and pathogenicity of Fusarium proliferatum causing stem rot of Hylocereus polyrhizus in Malaysia. Ann. Appl. Biol. 2013, 163, 269-280. [CrossRef]

23. Chang, K.; Hwang, S.; Conner, R.; Ahmed, H.U.; Zhou, Q.; Turnbull, G.D.; Strelkov, S.E.; McLaren, D.L.; Gossen, B.D. First report of Fusarium proliferatum causing root rot in soybean (Glycine max L.) in Canada. Crop. Prot. 2015, 67, 52-58. [CrossRef] 
24. Baudry, A.; Morzieres, J.P.; Larue, P. First report of Japanese pear black spot caused by Alternaria kikuchiana in France. Plant Dis. 1993, 77, 428. [CrossRef]

25. Li, L.; Pan, H.; Chen, M.; Zhang, S.; Zhong, C. Isolation and identification of pathogenic fungi causing postharvest fruit rot of kiwifruit (Actinidia chinensis) in China. J. Phytopathol. 2017, 165, 782-790. [CrossRef]

26. Li, Q.; Chen, L.; Yu, Y.; Wang, Y.; Zhu, P.; Xu, L.; Nonomura, T.; Matsuda, Y.; Toyoda, H. Phomopsis vaccinii: The Main pathogen causing market diseases in Kiwifruit. Ann. Rept. Kansai Plant Prot. 2015, 57, 31-35. [CrossRef]

27. Babadoost, M.; Pavon, C.; Islam, S.Z.; Tian, D. Phytophthora blight (Phytophthora capsici) of pepper and its management. Acta Hortic. 2015, 1105, 61-66. [CrossRef]

28. Hausbeck, M.K.; Lamour, K.H. Phytophthora capsici on Vegetable crops: Research progress and management challenges. Plant Dis. 2014, 88, 1292-1303. [CrossRef]

29. Maienfisch, P.; Hall, R.G. The importance of fluorine in the life science industry. CHIMIA Int. J. Chem. 2004, 58, 93-99. [CrossRef]

30. Exner, O.; Krygowski, T.M. The nitro group as substituent. Chem. Soc. Rev. 1996, 25, 71-75. [CrossRef]

31. Boyd, D.B. Electronic structures of cephalosporins and penicillins. 15. Inductive effect of the 3-position side chain in cephalosporins. J. Med. Chem. 1984, 27, 63-66. [CrossRef] [PubMed]

32. Sahu, P.K. Design, structure activity relationship, cytotoxicity and evaluation of antioxidant activity of curcumin derivatives/analogues. Eur. J. Med. Chem. 2016, 121, 510-516. [CrossRef] [PubMed]

33. Cherdtrakulkiat, R.; Boonpangrak, S.; Sinthupoom, N.; Prachayasittikul, S.; Ruchirawat, S.; Prachayasittikul, A. Derivatives (halogen, nitro and amino) of 8-hydroxyquinoline with highly potent antimicrobial and antioxidant activities. Biochem. Biophys. Rep. 2016, 6, 135-141. [CrossRef] [PubMed]

34. Gillis, E.P.; Eastman, K.J.; Hill, M.D.; Donnelly, D.J.; Meanwell, N.A. Applications of fluorine in medicinal chemistry. J. Med. Chem. 2015, 58, 8315-8359. [CrossRef] [PubMed]

35. Smart, B.E. Fluorine substituent effects (on bioactivity). J. Fluor. Chem. 2001, 109, 3-11. [CrossRef]

36. Liang, T.; Neumann, C.N.; Ritter, T. Introduction of fluorine and fluorine-containing functional groups. Angew. Chem. Int. Ed. 2013, 52, 8214-8264. [CrossRef] [PubMed]

37. Liao, S.; Shang, S.; Si, H.; Shen, M.; Rao, X.; Song, Z. Synthesis and antibacterial activity of myristyl carboxylate. Chem. Ind. For. Prod. 2015, 35, 33-38.

38. Liao, S.; Rao, X.; Shen, M.; Si, H.; Song, J.; Shang, S.; Song, Z. New hybrids derived from the natural compound (-)- $\beta$-pinene and amides or acylthioureas as antitumor agents. Lett. Drug Des. Discov. 2019. [CrossRef]

Sample Availability: Samples of the compounds are not available from the authors.

(C) 2019 by the authors. Licensee MDPI, Basel, Switzerland. This article is an open access article distributed under the terms and conditions of the Creative Commons Attribution (CC BY) license (http://creativecommons.org/licenses/by/4.0/). 